\title{
ZYGMUNT HAJDUK, STRUKTURY METODOLOGICZNE W NAUCE. SŁOWA KLUCZE FILOZOFII NAUKI, WYDAWNICTWO KUL, LUBLIN 2016, SS. 315.
}

Nauka w XX wieku stała się przedmiotem intensywnych badań. Szczególne zainteresowanie budzą zwłaszcza nauki przyrodnicze, głównie fizyka, pozwalające wnikać coraz głębiej w strukturę rzeczywistości materialnej i dzięki temu w istotny sposób zmieniać otaczające człowieka środowisko. Pytania, dlaczego metoda eksperymentalna okazała się tak skuteczna, dlaczego matematyka jest wykorzystywana w teoriach naukowych, jak odróżnić naukę od tego, co nie jest nauką, w jaki sposób rozwija się wiedza naukowa, wyznaczają zakres badań z obszaru filozofii nauki. Zarazem wielość odpowiedzi na powyższe pytania ukazuje, jak interesującym zjawiskiem jest nauka. Literatura dotycząca filozoficznych problemów, jakie stwarza nauka, jest ogromna; również w Polsce powstało wiele ważnych pozycji z tego zakresu. Czy zatem jest jeszcze miejsce na nową książkę z filozofii nauki?

Zygmunt Hajduk w swej najnowszej pracy pt. Struktury metodologiczne w nauce. Stowa klucze filozofii nauki nie powiela dotychczasowych ujęć. To, co odróżnia jego książkę od innych pozycji z obszaru filozofii nauki, to obecne w niej dwie przeplatające się ze sobą warstwy: przedmiotowa i metaprzedmiotowa. Przedmiotem głównym, którego dotyczy książka, jest oczywiście nauka ujmowana w szerokim kontekście jako zmieniający się wytwór społeczności naukowców, osadzony w kulturze i cywilizacji i mający ogromny wpływ na otaczającą człowieka rzeczywistość. Ale w monografii obecna jest również warstwa metaprzedmiotowa. Jest to mianowicie refleksja nad 
zmieniającą się filozofią nauki, czy dokładniej, jak ujmuje to Hajduk, wieloma filozofiami nauki. Autor pokazuje bowiem nie tylko, jak zmieniała się nauka, ale również jak modyfikowała się filozofia nauki, jakie następowały w niej przeobrażenia, jak zmieniał się zakres badanych tematów. Hajduk przedstawia całą panoramę badawczą - od pozytywizmu, dla którego przedmiotem zainteresowania była gotowa, ukształtowana teoria, a więc wytwór, przez stopniowe wprowadzanie kategorii odkrycia naukowego, aż po badanie rzeczywistej pracy uczonych, którzy, co warto podkreślić, nie bardzo przejmują się ustaleniami metodologów, logików czy filozofów nauki.

Książka składa się z dziesięciu rozdziałów poprzedzonych Wprowadzeniem. W kolejnych częściach zostały omówione tak istotne pojęcia, jak: teoria, wyjaśnianie, obserwacja, związek przyczynowy, modalność, rewolucja naukowa, redukcja, redukcjonizm. Według Hajduka, głównym zagadnieniem współczesnej filozofii nauki jest problem rozwoju wiedzy naukowej (s. 47). Toteż wydaje się, że głównym słowem-kluczem do całej książki jest słowo 'zmiana'. Zmieniającej się, ujmowanej temporalnie nauce, a także różnym związanym ze zmiennością kategoriom jest poświęcona cała monografia.

We Wprowadzeniu można znaleźć uzasadnienie tytułu monografii. Wytwór poznania naukowego jest mianowicie określany jako struktura, które to pojęcie jest rozumiane szeroko, a nie tylko w wąskim przyjmowanym w logice sensie. „Struktury metodologiczne” zatem należy pojmować, jak się wydaje, jako wszelkie badane w filozofii nauki jednostki związane $\mathrm{z}$ naukami, jak również te pojęcia, które dotyczą samej filozofii nauki. W swej pracy Hajduk dokonuje podziału struktur związanych $\mathrm{z}$ nauką (na stronie 10. znajduje się schemat), a następnie pokazuje, jak zmieniało się podejście do nich w filozofii nauki. W konsekwencji, według Hajduka, nie mamy do czynienia z filozofią czy metodologią (liczba pojedyncza) nauki, ale $\mathrm{z}$ wieloma filozofiami i metodologiami nauki. Autor wielokrotnie podkreśla pluralizm filozofii nauki. Ten pluralizm ujawnia się m.in. w wyraźnej zmianie aspektów badawczych: $\mathrm{z}$ rekonstrukcji teorii za 
pomocą logiki, czy teorii mnogości, w kierunku arekonstrukcjonizmu uwzględniającego, obok logicznej struktury teorii naukowych i ich odniesienia do badanej rzeczywistości, cały kontekst uprawiania nauki łącznie z uwarunkowaniami psychologicznymi, społecznymi, kulturowymi, politycznymi czy ekonomicznymi. Znaczenie ma również to, że naukę przestaje się ujmować atemporalnie, a traktuje się ją jako proces, zjawisko zmieniające się i rozwijające się w czasie. W kolejnych rozdziałach Hajduk zajmuje się tymi poszczególnymi zagadnieniami, zwracając szczególną uwagę na temporalne ujmowanie nauki. Ten problem był już przedmiotem zainteresowania Autora w jego książce: Temporalność nauki. Kontrowersyjne zagadnienia dynamiki nauki (RW KUL, Lublin 1995). Hajduk nie tylko patrzy na naukę jako na „badanie obiektów i struktur występujących w świecie” (s. 19), ale podkreśla to, że nauka jest przedsięwzięciem społecznym.

Rozdział pierwszy ma wyraźnie charakter metaprzedmiotowy: jego przedmiotem jest filozofia nauki. Hajduk określa podstawowe aspekty filozofii nauki: epistemologiczny, metafizyczny, etyczny, pedagogiczny oraz wymienia najważniejsze zagadnienia badane w filozofii nauki: cele nauki, granice i ograniczenia nauki, odkrycie naukowe, wyjaśnianie. Specyfika filozofii nauki jest spowodowana szczególnym przedmiotem badania. Wiedza naukowa bowiem zmienia się, „ma charakter próbny” (s. 25). Taki stan rzeczy jest spowodowany tym, że „nie mamy (...) bezpośredniego dostępu poznawczego do rzeczywistości, tak by można ją było odczytać raz na zawsze taką, jaka ona jest" (s. 26). Zmienność nauki wpływa na stawiane pytania a także na wprowadzanie nowych elementów, stających się przedmiotem zainteresowania filozofii nauki.

Hajduk zwraca też szczególną uwagę na znaczenie nauki w kulturze i cywilizacji. W tym kontekście rozpatruje dwa odmienne aspekty problemów aksjologicznych związanych z badaniami naukowymi, a mianowicie wartości, którymi kierują się naukowcy w swojej pracy, oraz wartości, które służą do etycznej oceny skutków odkryć naukowców. 
W rozdziale pierwszym Hajduk podkreśla wielokrotnie, że mamy do czynienia z pluralizmem filozofii nauki. Wiąże się z tym ściśle wielość metod stosowanych przez filozofów nauki, inne metody będzie stosował np. rekonstrukcjonista, a inne arekonstrukcjonista (s. 40).

Drugi rozdział został poświęcony omówieniu najważniejszej kategorii badanej w filozofii nauki, a mianowicie kategorii teorii, wokół której ogniskują się różne problemy z zakresu filozofii nauki. Teoria bowiem stanowi podstawową jednostkę strukturalną wiedzy (s. 41), toteż badanie jej struktury jest jednym z głównych zadań filozofii nauki. Co więcej, podejście do problemu teorii unaocznia to, jak zmieniała się sama filozofia nauki. Hajduk wskazuje przede wszystkim na to, że następowało przesuwanie akcentów $\mathrm{z}$ badania węższych jednostek, jak pojęcia, zdania, hipotezy, na badanie większych struktur, jak teorie i paradygmaty.

Następnie Hajduk omawia zagadnienie kryteriów, które pozwalałyby na odróżnienie nauki od nie-nauki. Takich kryteriów proponowano wiele, ale Autor zapatruje się na takie przedsięwzięcie pesymistycznie i podaje przyczyny, dlaczego do tej pory nie udało się ich sformułować (s. 46).

W dalszej części Hajduk omawia różne koncepcje teorii empirycznych: tradycyjne, deskryptywne, uhistorycznione, strukturalistyczne, konwencjonalistyczne, semantyczne, z perspektywy pojęciowej, koncepcję Brenta Mundy'ego, która stanowi modyfikację tradycyjnego ujęcia wypracowaną w odpowiedzi na krytykę tego stanowiska. Ten przegląd pokazuje, jak bogate treści zawiera pojęcie teorii naukowej. Stanowi jednocześnie tło dla następnych podejmowanych w monografii tematów.

Jednym z nich jest problem wyjaśniania. Wyjaśnianie jest istotną kategorią rozpatrywaną w filozofii nauki, gdyż jednym z celów nauki jest zrozumienie rzeczywistości. W przypadku tej kategorii również istnieje wielość modeli wyjaśniania, co wiąże się z rozmaitością rodzajów wyjaśniania. Hajduk dokonuje interesującego zabiegu, odróżniając modele wyjaśniania (np. model Carla Hempla) od paradygmatów wyjaśniania, których wyróżnia trzy rodzaje: paradygmat 
uogólnionego prawa, paradygmat wyjaśniania zdeterminowany przez reguły i paradygmat neorealistyczny. Ważne w pracy są analizy kontrowersji dotyczących teorii wyjaśniania. Dają one podstawy do zwrócenia uwagi na aspekty pragmatyczne wyjaśniania. Podnoszone są one m.in. w teorii wyjaśniania Petera Achinsteina.

Następnym ważnym problemem dotyczącym teorii jest zagadnienie związku teorii z obserwacją, co jest treścią rozdziału czwartego. W tym rozdziale Hajduk kładzie szczególny nacisk na problem relacji między terminami obserwacyjnymi a teoretycznymi. Podział ten, jak wiele problemów w filozofii nauki, pochodzi od neopozytywistów i budzi wiele kontrowersji. W tym kontekście Hajduk powraca również do sporu realizmu z instrumentalizmem, a także do wielokrotnie dyskutowanego problemu zależności obserwacji od teorii. Hajduk skłania się do uznania, że nie wszystkie obserwacje są zależne od teorii, jak się powszechnie uważa, a tym samym teoretyczny relatywizm nie jest nieunikniony (s. 154). Omawia też problem interpretacji terminów teoretycznych i problem tego, co jest obserwowalne. Hajduk uważa, że podział obserwowalne - nieobserwowalne nie wydaje się być przydatny (s. 163). Co więcej, choć teorie są odrzucane, to „większość dawnych typów obserwacji (...) nie została odrzucona, lecz je rozbudowano czy odpowiednio doskonalono" (s. 164). Świadczy to o kumulatywnym charakterze nauki. W tym kontekście Hajduk deklaruje się jako realista naukowy: „Realizm naukowy, jaki mamy na względzie, jest charakteryzowany poprzez tezy: odpowiednio sformułowany język teoretyczny jest sensowny; jesteśmy zasadnie przekonani o twierdzeniach teoretycznych właściwie skonfirmowanych teorii; wiedza naukowa jest obiektywna. $\mathrm{Na}$ taki charakter wskazuje kumulatywność nauki” (s. 165).

Kontynuacją rozważań dotyczących terminów teoretycznych jest rozdział piąty: State deskryptywne w stowniku jezyka nauki. Hajduk stawia tu pytanie o rolę terminów teoretycznych w nauce, a mianowicie, czy terminy te są konieczne w nauce, czy też cele nauki można osiągnąć bez nich. Hajduk omawia tzw. „dylemat teoretyka”, 
stanowiący argument za zbędnością terminów teoretycznych wysuwany przez instrumentalistów i empirystów, lecz sam opowiada się za niezbędnością terminów teoretycznych w nauce. Zwraca jednak uwagę, że podział terminów na teoretyczne i obserwacyjne nie jest wyczerpujący i proponuje podział terminów na deskryptywne (opisujące) i nieobserwacyjne (wyjaśniające) (s. 182). Według Hajduka ta klasyfikacja, choć może budzić zastrzeżenia, to unika trudności, „które były wysuwane pod adresem tradycyjnej dychotomii terminów teoretycznych i obserwacyjnych" (s. 183).

Ważną kategorią dotyczącą nauki jest kategoria przyczynowości, która jest ściśle związana z kategorią wyjaśniania. Wyjaśnienie jest to bowiem m.in. podanie przyczyn wystąpienia danego zdarzenia czy stanu rzeczy. Problem natury przyczynowości Hajduk analizuje w rozdziale szóstym, skupiając się na jednostkowych zdaniach kauzalnych. Prezentuje tu szereg koncepcji przyczynowości, od klasycznego ujęcia Davida Hume’a, przez koncepcję nomologiczną, aktywnościową (manipulatywną), warunków, kontrfaktyczności aż po ujęcie probabilistyczne. W rozdziale siódmym zaś omawia kategorię modalności.

W ostatnich trzech rozdziałach monografii Hajduk przechodzi do problemów dotyczących nauki jako całości. Omawia kolejno: kategorię rewolucji naukowych, redukcję i problem jedności nauki. Kategoria rewolucji naukowej pojawia się w kontekście pytań o charakter zmian w nauce. Hajduk wymienia typy rewolucji. Poszukuje też w historii nauki okresów rewolucyjnych. Dokonuje mianowicie podziału dziejów nowożytnych nauk przyrodniczych na dwa wielkie okresy: od systemu Kopernika do systemu mechaniki Newtona (1543-1747) (kształtowanie się podstaw nowożytnego przyrodoznawstwa) i od systemu filozofii Kanta oraz prac Lavoisiera do połowy lat 70. XX wieku (1770-1965). Wskazuje w nich na szczególnie ważne momenty, które można uznać za rewolucyjne. Stwierdza, że w ostatnich dwustu latach nastąpiło prawie dwadzieścia rewolucji w ośmiu dziedzinach. Zatem przeciętnie co dwanaście lat mamy do czynienia z jedną rewolucją (s. 240). 
W rozdziale dziewiątym Hajduk zajmuje się problemem redukcji. Kwestie te są ważne w kontekście prób redukcji nauk o życiu do fizyki i chemii. Hajduk wymienia typy redukcji. W rozdziale ostatnim podejmuje zaś problem jedności nauki.

W monografii ważne jest uwypuklanie problemów metateoretycznych, w szczególności pokazywanie swoistych przewrotów czy wręcz rewolucji w filozofii nauki, w której zmieniały się badane problemy, a także metody badawcze. Taką rewolucją w filozofii nauki było podjęcie badań dynamiki nauki i zerwanie $z$ traktowaniem jej jako statycznego wytworu działania naukowców. Zaowocowało to zmianą badanych zagadnień dotyczących fundamentalnych pojęć, jak wyjaśnianie, konfirmacja, indukcja, struktura teorii, $\mathrm{z}$ ujęcia statycznego na ujmowanie ich z punktu widzenia procesu rozwoju nauki. Również rewolucyjne znaczenie miało przesunięcie akcentów $z$ badania poszczególnych jednostek ku badaniu związków między nimi.

Wprawdzie książka stanowi swoisty zapis wykładów z filozofii nauki prowadzonych przez ks. prof. Hajduka, to swym zakresem, bogactwem materiału, szczególnym ujęciem zarówno samej nauki, jak i filozofii nauki daleko wykracza poza zakres wykładu monograficznego. Zawiera oprócz propozycji rozwiązań pewnych problemów, również wiele kwestii dyskusyjnych i stawia nowe pytania. Należy podkreślić, że stanowisko Hajduka unika skrajności i radykalnych ocen. Sam Autor określa siebie jako realistę naukowego, wskazuje, że choć teorie są odrzucane, to mimo wszystko nauka ma kumulatywny charakter, zaś problemu współmierności czy niewspółmierności paradygmatów nie widzi w sposób zero-jedynkowy, lecz twierdzi, że rewolucja nie musi oznaczać całkowitego zerwania ciągłości.

ANNA LEMAŃSKA

a.lemanska@uksw.edu.pl

Uniwersytet Kardynała Stefana Wyszyńskiego w Warszawie, Instytut Filozofii

Wóycickiego 1/3, 01-938 Warszawa

DOI: 10.21697/spch.2017.53.4.31 